Russian, and one of $£ 20,000$ over 3 years to the Language Research Centre, Birkbeck College, London, for a scheme of research into applied linguistics and the psychology of language learning. A grant of up to $£ 20,700$ over 3 years was made to the Department of Child Life and Health, University of Edinburgh, for investigations of the development of speech in young children. Grants to the new universities include one of $£ 63,000$ over 5 years to the University of York toward the development of a. Language Teaching Overseas Centre.

Grants for the Commonwoalth overseas include a final grart of $£ 15,000$ ovor 6 years to the Plunkett Foundation for Co-operativo Studies, for the development of residential training courses for staffs of agricultural co-operative departments and societies in East and West Africa. Further and final support is being given to the Economic Fellowships of the Oversees Dovelopment Institutes by a grant of $£ 15,400$ over 2 years, and one of $£ 24,000$ was made to the Institute of Education, University College of Dar es Salaam, for the building of a Science Contre. A capital grant of $£ 27,600$ was mado to the University College of Fisst Africa, University College of Makerere Modical School, to build an extension to the modical library, while a grant of $£ 8,250$ was made to support, within the Serengeti Research Project, a 3-year study of animal ecology in the Tanganyika National Parks. The Starehe Boys' Centre in Nairobi received a grant of $£ 18,650$ to provide a secondary school. A grant of $£ 2,160$ over 3 years was made to the University of Melbourne for continuation of investigations of the motabolism and water relations of Australian heath plants. A further grant of $£ 30,000$ to the University of the West Indies was partly towards providing guest-house accommodation for postgraduate visitors, and partly for the establishment of a centre for extramural studies in the Leeward and Westward Islands. One of $£ 10,700$ was made towards the capital cost of developing the Fields Studies Centre of the University of Malaya, including tho provision of accommodation, and ono of $£ 25,500$ for a 3-year investigation of agricultural marketing in Mauritius.

Awards for the United Kingdom in medicine and dentistry continued unchanged, but the conditions for dental rosearch fellowships were slightly altered to facilitate a wider choice of candidates; one medical research fellowship and two ordinary fellowships were awarded and twenty-four scholarships in tropical medicine. Two scholarships and four bursaries were awarded in biology and four scholarships in sociology. Under schemes for the Commonwealth, ovorseas travelling fellowships for graduates for one year's study were awarded to scholars from Australia, Ceylon, India, Pakistan and Now Zealand. Two of those were in medicine, eight in the natural sciences and six in the humanities and social sciences. Shorter travelling fellowships for six months were awarded to throe public officials and two Trade Unionists from Canada, and nine short-term travel grants were made to senior Canadian scholars (two being in the natural sciences, three in the humanities and four in medicine). The travelling fellowship for a Dominion practitioner was last year awarded to Canada; Dominion travelling scholarships were again awarded to two farmers each from Canada, Australia and New Zealand, and one each from Rhodesia, Zambia and Konya. 'The Foundation's original grant of $£ 50,000$ over 10 years to the Royal Society and Nuffield Foundation Commonwealth Bursary Scheme was renewed for a further and final period of 5 years at the same rate of $£ 5,000$ a year and, in 1964, twenty-two awards were made. So far, 330 grants have been made from the Elizabeth Nuffield Educational Fund, fifty-two being made during the year.

\title{
PUBLICATIONS OF THE WORLD HEALTH ORGANIZATION
}

$\mathrm{T}$ HE World Health Organization, in accordance with its Charter, publishes a large number of authoritative books and pamphlets in various fields of public health, and in more specialized fields of medicine. The following recent publications will be of interest to a wide spectrum of workers in these fields.

The Animal Health Yearbook for 1964 is the eighth issue of the series of yearbooks bearing this title published jointly by the Food and Agriculture Organization of the United Nations, the World Health Organization and the Office Internationale des Épizooties (FAO-WHO-OIE. Animal Health Yearbook, 1964. Pp. vi+316. Rome: Food and Agriculture Organization of the United Nations; London: H.M.S.O., 1965. 17s. 6d.; 3.50 dollars). The present volume, like its predecessors, contains 316 large pages of detailed information about the incidence and distribution of diseases of livestock all over the world. Printed in English, French and Spanish, it also gives the Latin names of the causative agents of all the diseases listed. A triumph of clear printing and classification of the astonishing range of information collected from replies to questionnnaires sent to the veterinary services in all the countries represented, it constitutes an invaluable summary of the state of animal health all over the world. This year it includes information about the diseases of fish and bees and also an article on the livestock disease position in 1964, and this issue contains for the first time a Russian glossary compiled at the headquarters of the Food and Agriculture Organization from the veterinary literature consulted. An additional valuable feature is the reference index at the end of the volume containing all the terms applied to the various diseases listed in the tables, together with secondary titles, synonyms and causal agents in English, French and
Spanish and also other accepted international nomenclatures.

Another valuable publication of the Food and Agriculture Organization is the paperback volume entitled Fascioliasis and the Liver Fluke (Food and Agriculture Organization of the United Nations. FAO Agricultural Studies No. 64. Pp. xxi +234 . Rome: Food and Agriculture Organization of the United Nations; London: H.M.S.O., 1964. 15s.; 3 dollars), the publication of which has been made possible by a generous grant from Ciba, Ltd., of Basle, as a contribution to the Freedom from Hunger campaign. Written by Dr. R. L. Taylor, who, until recently, was deputy director of the Central Veterinary Laboratory of the Ministry of Agriculture at Weybridge, Surrey, this volume carries all the authority of an author whose knowledge of the subject is derived from many years of practical investigation of fascioliasis, in col. laboration with his colleagues at the Weybridge laboratory. In this book, Taylor emphasizes the ecological aspects of the disease, which he regards as being a derangement of a naturally healthy relationship between grazing animals and the flukes. He presents the methods of control on farms as artificial adjustments which endeavour to re-establish a normal situation rather than to eradicate a harmful parasite. Taylor does not discuss the serious disease that this fluke may cause in man and, no doubt, he would agree that human fascioliasis is anything but a normal healthy relationship between parasite and host.

Discussing the grave losses caused among livestock by Fasciola hepatica, Taylor points out the great difficulty of assessing these accurately, but there is little doubt that, when severe outbreaks of fascioliasis occur, in any country, millions of sheep may be killed by it. He then describes 
the anatomy of $F$. hepatica, and its biology, and in an interesting chapter he traces the development, step by step over the years, of our knowledge of the life-history of this fluke, from the first recorded reference to it by Jcan de Brie in the time of Charles V of France. He then discusses in considerable detail the ecology, life-history and habitats of the intermediate host, the snail, Inymnaea truncatula, which is the chief intermediate host in Britain, although other species of snail are intermediate hosts in other countries. Succeeding chapters discuss the pathogenicity of $H^{\prime}$. hepatica, the pathology of fascioliasis, the clinical features of the acute and chronic forms of the disease, and its treatment. Next is discussed the rapidly fatal black disease of sheep, caused by Clostridium oedematiens infecting the liver when this has been damaged by $F$. hepatica. Another chapter discusses the disease caused by Fasciola gigantica, the differentiation of this species from $F$. hepatica and the various species of Lymnaea that are its intermediate hosts, together with their biology, the losses caused by this species in Pakistan and Uganda and methods used for control of the disease.

In a final chapter, Taylor discusses prospects for the future control of this very grave disease. A valuable bibliography concludes a volume which cannot fail to be of great value and interest to all agriculturists, especially those who are concerned with the rearing of shoop and cattle. Many readers will, no doubt, wish that it could have been issued in a more durable binding.

Aspects of Family Mental Health in Europe (World Health Organization. Public Health Papers, No. 28. Contributed by D. Buckle et al. Pp. 123. Geneva: World Health Organization; London: H.M.S.O., 1965. $5 \mathrm{Sw}$. francs; $8 s .6 d . ; 1.75$ dollars), by ten European authors, has as its themo that mental illness cunnot adequately be treated by confining treatment to the individual who is mentally ill, but must be dealt with in the light of the individual's social environment and of disturbances which affect other members of his family. The papers deal with the work of the School for Parents which originated in Paris and that of the Hampstead Child Therapy Clinic and with family psychotherapy as it is practised in Czechoslovakia. They demonstrate the complexity of the subject and of the various approaches being made to it in different parts of Europe.

Mass Campaigns and General Health Services, by C. L. Gonzalez (World Health Organization. Public Health Papers, No. 29. Pp. 87. Geneva: World Health Organization; London: H.M.S.O., 1965. 4 Sw. francs; 6s. 8d.; 1.25 dollars), gives the preliminary results of an investigation of this complex subjoct. It is so complex that it is impossible to summarize briefly the contents of this volume, but it should interest everyone who has responsibility for health services in areas in which mass campaigns against particular diseases may have to be integrated into general health services.

Nutrition and Infection-Report of a WHO Expert Committee (World Health Organization. No. 314. I'p. 30. Geneva: World Health Organization; London: H.M.S.O., 1965. $2 \mathrm{Sw}$. francs; $3 s .6 d . ; 0.60$ dollar) discusses the effects of malnutrition on morbidity and mortality caused by infectious disease and experimental investigations of this. Other sections of the report discuss the effect of infoction on nutritional investigations, mechantisms of synergism and antagonism and the education of physicians and public health workers. Other sections offer recommendations and suggestions for research.

Special Courses for National Staff with Higher Administrative Responsibilities in the Health Services (World Health Organization. No. 311. Pp. 31. Geneva: World Hoalth Organization; London: H.M.S.O., 1965. $2 \mathrm{Sw}$, francs; $3 s .6 d . ; 0.60$ dollar) gives the views of a World Health Organization Study Group on the training required by those who adopt health services as a career. Annexes give details of existing training programmes in the University of Zagreb, the School of Hygiene in the
University of Toronto, the Johns Hopkins University, the National Institute of Health Administration and Education, New Delhi, and in the Staff Training Programme of WHO.

Diabetes mellitus-Report of a WHO Expert Committee (World Health Organization. No. 310. Pp. 44. Geneva: World Health Organization; London: H.M.S.O., 1965. $3 \mathrm{Sw}$. francs; $5 s . ; 1$ dollar) discusses the natural history, detection, prevention and control of diabetes and the employment of diabeties, with suggestions for research on the disease.

Vol. 19, No. 11, of WHO Chronicle (price 1s. 9d. from H.M.S.O., P.O. Box 569, London, S.E.1) discusses hospital organization in developing countrjes, the health problems of adolescence, the World Health Organization's programme on nutrition and international non-proprietary names given to pharmaceutical preparations. In the "Notes and News" section thero are notes on cholera outbreaks in Iran, Afghanistan and the U.S.S.R., on mycoses in Africa and on the collaboration between the World Health Organization and the London Zoo in comparative medicine.

Dependence-producing Drugs (World ITealth Organization. No. 312; WHO Expert Committee on Dependenceproducing Drugs---Fourteenth Report. Pp. 16. Geneva: World Health Organization; London: H.M.S.O., 1965. $2 \mathrm{Sw}$. francs; $38.6 d$; 0.60 dollar) contains an annexe which gives a list of drugs that are under international narcotics control.

The August issue of the WHO Chronicle (price 1s. 9d., from H.M.S.O., P.O. Box 569, London, S.E.1) contains a report on the Proccedings of the eighteenth World Health Assembly held in Geneva in May 1965, an article on the work of the World Health Organization in relation to population problems, and another on activities assisted by the World Health Organization in tho campaign against tuberculosis, an account of the report of the World Health Organization Expert Committee on nutrition in pregnancy and lactation, together with the customary feature entitled "Notes and News" and short reviews of three World Health Organization publications. The September issue of this Chronicle contains articles on malaria eradication in 1964, research on cardio-vascular diseases, work on tuberculosis assisted by the World Health Organiza. tion, the chomoprophylaxis of primary tuberculosis, and a useful article on changes in hoalth legislation in various countries in Europo, South America, India and Anstralia.

World Health Organization Technical Report Series No. 309 is a joint publication with the Food and Agriculture Organization entitled Specifications for the Identity and Purity of Food Additives and their Toxicological Evaluation, Food Colours and some Antimicrobials and Antitoxidants (World Health Organization. Eighth Report of the Joint FAO/WHO Expert Committee on Food Additives. Pp. 25. Geneva: World Health Organization; London: H.M.S.O., 1965. 2 Sw. francs; 3s. $6 d$.; 0.60 dollar). It omphasizes tho need for international establishment of specifications for the idontity and purity of food additives, which should not only protect the consumer, but should also help the manufacturers and those who procoss foods.

No. 26 of the invaluable sories of World Health Organization Public Health Papers, written by Prof. E. M. Blackett, of the University of Aberdeen, deals with the grave subject of domestic accidents, which, unlike the road accidents which are so often in the news, roceive little publicity (World Health Organization. Domestic Accidents. Pp, 137. Geneva: World Health Organization; London: H.M.S.O., 1965. $6 \mathrm{Sw}$. franes; $10 s . ; 2$ dollars). Yet in many countries deaths due to domestic accidents аге comparable in number to those due to tuberculosis. The study of them on an international basis is complex and much of the literature about therm is obscure, yet thoso accidents are, this publication suggosts, likely to 
become more and more a public health problem in the future. Control of disease and the resulting increase of the population are leading to increasing numbers of old people and children, who are particularly liable to domestic accidents. Mechanization in the home also tends to increase their number and variety.

No. 27 of the same series is entitled T'rends in the Study of Morbidity and Mortality, and it contains articles on this subject by fourteen contributors (World Health Organization. Public Health Papers, No. 27: Trends in the Study of Morbidity and Mortality. Dario Curiel and thirteen other authors. Pp. 196. Geneva: World Health Organization; London: H.M.S.O., 1965. 8 Sw. francs; 13s. $4 d . ; 2.27$ dollars). In general, the articles survey the methods now in use for obtaining statistics on morbidity and mortality in the United Kingdom, Europe, Romania, Japan and India, and the problems of making the data obtained internationally comparable. There is need for further research into methods of reporting and for the establishment of some degree of uniformity.

\section{RESEARCH FACILITIES AVAILABLE TO INDUSTRY AND THEIR INTER-RELATION}

\begin{abstract}
CLOSER collaboration between industrial, govern1 mental, academic and independent research establishments was the principal theme and objective of the symposium arranged jointly on September 14, 1965, by the Scottish Office of the Ministry of Technology and the Arthur D. Little Research Institute, at the Royal Society of Edinburgh. The seven speakers at the symposium were ollowed by Sir Harry Melville, who described the varied work of the newly formed Science Research Council. of which he is chairman, this lecture being the first of the Arthur D. Little 1965-66 series of Acorn Lectures on various scientific topics.
\end{abstract}

Mr. P. M. Thomas (managing director, William Beardmore and Co., Ltd.), in the chair for the morning session, directed attention to the necessity for industry to make proper use of research facilities and so be aware of the present status of any topic relevant to the particular industry and the appropriate place to which to direct problems.

Prof. Manfred Gordon (Department of Physical Chemistry, University of Strathclyde) said that his University, formerly the Royal College of Science and Technology, always had a technical bias and strong links with industry. For example, the idea of industrial liaison officers, whose purpose is to establish co-operation between an academic establishment and industry, originated in 1956 at the then Royal College of Science and Technology. 'The University and the National Engineering Laboratory have special relationships and that some of the National Engineering Laboratory staff are registered as Ph.D. students. Many of the University staff act as consultants, but Prof. Gordon expressed the desirability of younger membors spending a fow weeks of the summer vacation in industry. Strathclyde now uses closed-circuit television for teaching, which could be a valuable technique to assist firms with their training problems. The computer service at the University was also mentioned.

Dr. Magnus Pyke (manager, Glenochil Research Station, Distillers Co., Ltd.) recalled that a few years ago some firms believed in leaving the research staff alone, in the hope that profitable ideas and proeesses would emerge. This procedure was found very expensive and not very profitable. To-day, practical problems are chosen for the research staff. However, Dr. Pyke stressed that applied research should be tackled at an intellectual depth in order for the results to be financially worth-while and stimulating to the staff. Non-secret technical know-how should be more widely disseminated between firms by personal contacts and a new journal.

The problem of assimilating the scientific literature could, he suggested, be solved by using computers to store information which would be released by 'telephoning'. Dr. Pyke, like other speakers, deplored the gap between industry and academic establishmonts in Britain, a situation which does not occur to the same extent on the Continent or in the United States, and called for more industry-orientated projects for research students in order to counteract an 'ivory tower' attitude.

Mr. F. D. Penny (deputy director, National Engineering Laboratory) gave a short historical survey of Government laboratories. Initially, during the seventeenth and eighteenth centuries, these were for defence purposes; later, civil laboratories were established, the Geological Survey being founded in 1835 and the Inland Revenue Laboratory in 1842. Others, of which the National Physical Laboratory was the first in 1900, were intended to determine fundamental and applied standards. In 1915 the important White Paper setting up the Department of Scientific and Industrial Research, which represented a conscious effort by the Government, appeared to take responsibility for improving industrial progress. Research programmes were not evolved in isolation but were controlled by committees of leading academies and industrialists.

The National Engineering Laboratory was opened in 1947, and, as with other Government laboratories, the work can be classified as follows: (1) particular problems -testing and longer-term research (the latter represents 10 per cent of the total work at the National Engineering Laboratory); (2) safety, for example, tests on gas cylinders; (3) problems applicable to a class of industry but not sponsored by any firm, for example, investigations of metal fatigue; (4) special facilities-testing of pumps and turbines; (5) research in a field of industrial im. portance in which the Government believes there should be a greater rate of innovation; (6) standards of goods for export; (7) advisory services.

The National Engineering Laboratory issues reports $(8,000$ total so far) and papers in scientific journals, welcomes visitors and holds open days. The total staff is 800 , and they spend about half their time on research and half on application.

Dr. H. P. Stout (director of research, British Jute Trade Research Association) pointed out how a research association benefits especially the smaller firms of an industry, since such firms usually cannot afford adequate scientific staff and, where facilities are available, may have difficulty in the recruitment of staff because there is no suitable environment for them. The research association can provide a scientific atmosphere, but there is still the problem of getting en rapport with the firms. Commenting on the statement sometimes heard that arts graduates were more use as management material than science graduates, he thought this was usually the result of the scientist boing given a specialist function and not acquiring the broad training and experience which was given to the arts man. Dr. Stout noted that innovation costs money and manufacturers are unwilling to develop ideas where the market is small, even after the research association has done the 'spade work'. He instanced new weaving machinery developed 